\title{
After the boring billion and before the freezing millions: evolutionary patterns and innovations in the Tonian Period
}

\author{
Shuhai Xiao and Qing Tang \\ Department of Geosciences, Virginia Tech, Blacksburg, VA 24060, U.S.A. \\ Correspondence: Shuhai Xiao (xiao@vt.edu)
}

Received: 13 March 2018 Revised: 7 May 2018 Accepted: 15 May 2018

Version of Record published: 29 June 2018
The Tonian Period (ca. 1000-720 Ma) follows the 'boring billion' in the Mesoproterozoic Era and precedes 'snowball Earth' glaciations in the Cryogenian Period. It represents a critical transition in Earth history. Geochemical data indicate that the Tonian Period may have witnessed a significant increase in atmospheric $\mathrm{pO}_{2}$ levels and a major transition from predominantly sulfidic to ferruginous mid-depth seawaters. Molecular clock estimates suggest that early animals may have diverged in the Tonian Period, raising the intriguing possibility of coupled environmental changes and evolutionary innovations. The co-evolution of life and its environment during the Tonian Period can be tested against the fossil record by examining diversity trends in the Proterozoic and evolutionary innovations in the Tonian. Compilations of Proterozoic microfossils and macrofossils apparently support a Tonian increase in global taxonomic diversity and morphological range relative to the Mesoproterozoic Era, although this is not reflected in assemblage-level diversity patterns. The fossil record suggests that major eukaryote groups (including Opisthokonta, Amoebozoa, Plantae, and SAR) may have diverged and important evolutionary innovations (e.g. multicellularity and cell differentiation in several groups, eukaryovory, eukaryote biomineralization, and heterocystous cyanobacteria) may have arisen by the Tonian Period, but thus far no convincing animal fossils have been found in the Tonian. Tonian paleontology is still in its nascent stage, and it offers many opportunities to explore Earth-life evolution in this critical geological period.

\section{A pressing need to improve the Tonian fossil record}

Geologist Roger Buick [1] wrote more than 20 years ago that 'the dullest time in Earth's history seems to have been the Mesoproterozoic, the era between 1600 and 1000 Ma ago'. The Mesoproterozoic Era has since been known as the 'boring billion'-a period of apparent quiescence as far as the global carbon cycle is concerned [1], although important evolutionary events did occur in the Mesoproterozoic [2-6]. In the grand scheme of Earth history, the Tonian Period follows the so-called 'boring billion' of the Mesoproterozoic Era [1] and precedes the Cryogenian 'snowball Earth' glaciations each lasting millions of years [7]. Because of its critical location in the geological timescale, the Tonian Period holds the key to understand how the Earth system transitioned into climatic catastrophes in the Cryogenian (Figure 1).

Emerging geochemical data indicate that atmospheric $\mathrm{pO}_{2}$ levels and oceanic redox structures may have experienced major changes in the Tonian Period [8] (Figure 1). Planavsky et al. [9] specifically proposed that atmospheric $\mathrm{pO}_{2}$ levels were prohibitively low for animal evolution until around $800 \mathrm{Ma}$ (but see [10,11]). Guilbaud et al. [12] showed that, while deep ocean waters may have remained anoxic and ferruginous, mid-depth seawaters shifted from predominantly sulfidic to largely ferruginous conditions in the Tonian Period. Reinhard et al. [13] argued that the late Tonian to Cryogenian Period (800-635 Ma) is characterized by intermediate $\mathrm{pO}_{2}$ levels and a transitional redox 


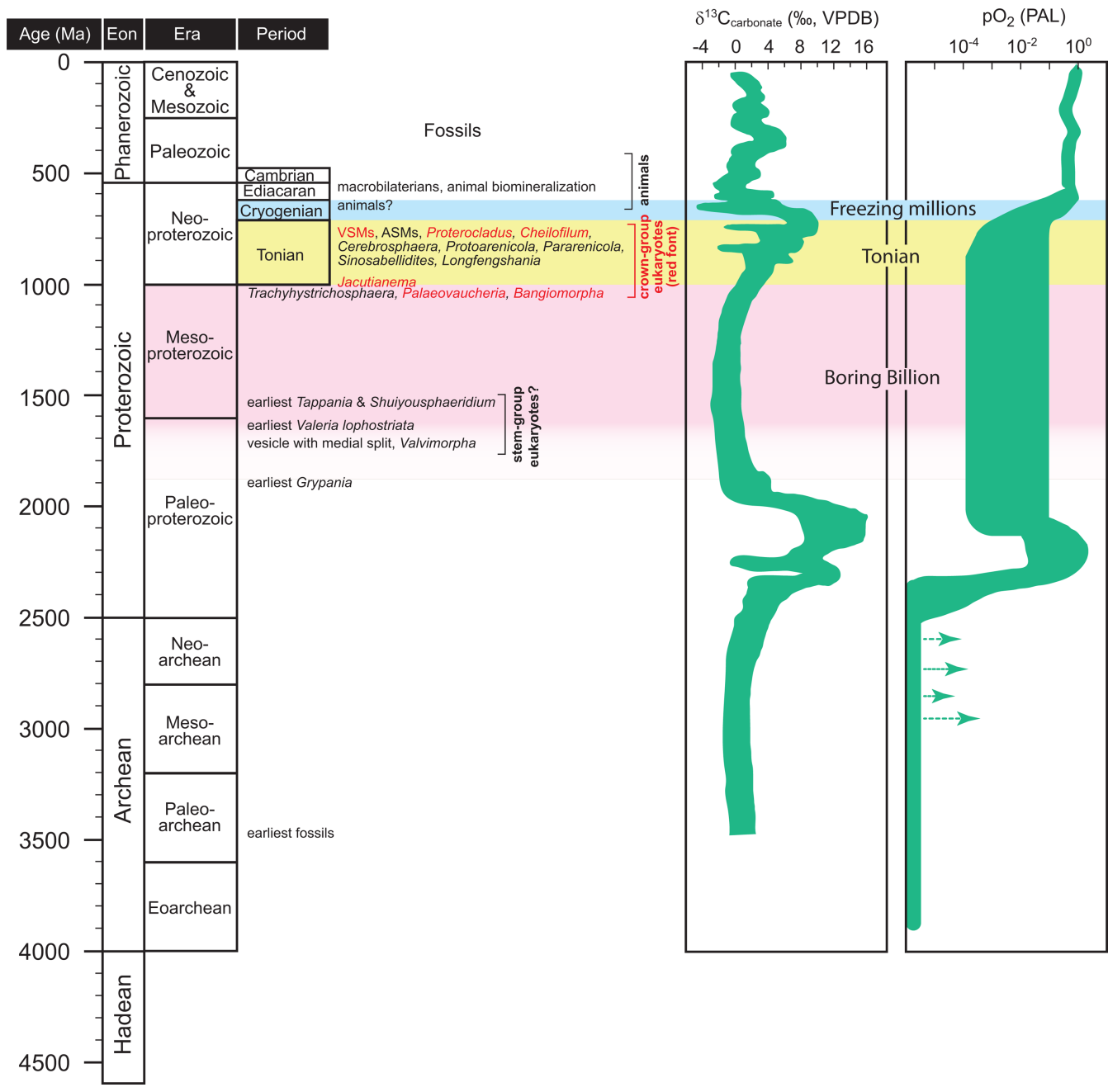

Figure 1. Geological timescale showing the Tonian Period (yellow) between the 'boring billion' (pink) and 'freezing millions' (blue).

Key fossils are listed next to the geological timescale. Carbonate carbon isotope curve and estimated atmospheric $\mathrm{pO}_{2}$ levels from ref. [8].

state between pervasively ferruginous and largely oxygenated deep oceans. They further hypothesized that fundamental changes in the global phosphorus and nitrogen cycles may have occurred in the late Tonian Period, due to the combined effects of a weaker deep-sea Fe-P trap (e.g. reduced removal of phosphorus from ferruginous deep waters as vivianite or green rust species) and enhanced production of nitrate that feeds denitrification, resulting in nitrogen limitation on biospheric productivity on geological timescales [13]. It is expected that these changes would have impacted biospheric evolution and stimulated evolutionary innovations [8], which may have in turn influenced further changes in oceanic redox structures [14]. Thus, it is critical to examine the Tonian fossil record and to more accurately document large-scale diversity patterns and evolutionary innovations in the Proterozoic, in order to explore the possible correlations and links between biospheric and environmental evolution during this key geological period.

Molecular clock estimates and biomarker fossils provide additional impetus to investigate the Tonian fossil record. Molecular clock data suggest that crown-group animals may have diverged in the Tonian Period [15,16], raising the intriguing possibility of close coupling between redox evolution and evolutionary innovations. Biomarker fossils indicate that marine eukaryotic algae did not come to ecological dominance until the Cryogenian and Ediacaran periods [17], although molecular clock and available paleontological data suggest 
that eukaryotic algae did evolve before the Tonian Period $[3,4,18,19]$. Thus, there are compelling reasons to bring the Tonian in the forefront of paleobiological investigation in order to better understand the co-evolution of life and the physical environment during this critical geological period. In this contribution, we summarize recent advances in Tonian paleobiology and identify opportunities for future research.

\section{Large-scale diversity patterns of Tonian eukaryotic fossils}

Tonian paleontological studies have been focused almost exclusively on microfossils, particularly organic-walled acritarchs, many of which have been interpreted as unicellular eukaryotes. A recent compilation of Proterozoic acritarchs and other eukaryotic fossils [20] shows that the assemblage-level taxonomic diversity (analogous to alpha diversity, or species richness at a site or locality) of Tonian assemblages, with a few exceptions, is comparable to that of Mesoproterozoic assemblages, but is significantly lower than that of Ediacaran ones (Figure 2A). Cryogenian assemblages tend to have lower taxonomic diversity, but this may be in part related to the dominance of coarse-grained and poorly fossiliferous glacial deposits in this geological period.

Existing compilations of global taxonomic diversity (analogous to gamma diversity, or total diversity at a global scale) show that the taxonomic diversity of Tonian acritarchs is significantly higher than in the Mesoproterozoic Era but lower than in the Ediacaran Period [21]. However, these compilations were completed more than 20 years ago and does not reflect the many recent discoveries of Proterozoic microfossils. A recent analysis focusing on Neoproterozoic data and using CONOP — an ordination technique to optimize the order of fossil appearances in the rock record-reveals that the rarefied global diversity shows an overall decreasing trend in the second half of the Tonian Period [22]. This decline precedes Cryogenian glaciations and is therefore unlikely to have been driven by glaciations.

Any estimate of taxonomic diversity of microfossils is necessarily susceptible to problems related to taxonomic treatment of fossil taxa (e.g. taxonomic splitting vs. lumping). To alleviate this problem, Huntley et al. [23] assembled a morphological database of Proterozoic acritarchs and carried out a morphometric analysis. Their results show that, although the documented morphological range of Tonian eukaryotes is greater than that of the Mesoproterozoic Era (Figure 2B), the morphological disparity as measured by dissimilarity and by variance is only marginally greater in the Tonian than in the Mesoproterozoic Period (Figure 2C). In contrast, both the morphological range and disparity are lower in the Tonian than in the Ediacaran Period, echoing the evolutionary pattern of taxonomic diversity.

Proterozoic macrofossils are typically preserved as carbonaceous compressions. They are relatively rare and their interpretation as eukaryotes are sometimes controversial. For example, the coiled macrofossil Grypania from the Paleo-Mesoproterozoic Era has been variously interpreted as a eukaryote [24] or a giant cyanobacterium [25]. Other phylogenetically unresolved carbonaceous macrofossils include the common Tonian fossils Chuaria and Tawuia [26,27], as well as various forms from the Paleo-Mesoproterozoic successions in North China [28-30]. These problems make it difficult to obtain a reliable picture of large-scale diversity pattern of Proterozoic eukaryotic macrofossils. The only compilation of Proterozoic carbonaceous compression macrofossils was published more than a decade ago [31]. Despite the limited number of macrofossils included in this database, the analysis shows that Tonian macrofossils do occupy a greater morphological range than Mesoproterozoic ones (Figure 2D), although the morphological disparity as measured by variance is comparable between Tonian and Mesoproterozoic, and the morphological range and disparity are both lower in the Tonian than in the Ediacaran Period (Figure 2E). Cryogenian carbonaceous compression macrofossils [32] are too few to warrant any meaningful analysis.

To summarize, the fossil record shows a consistent pattern that the Ediacaran Period exhibits greater taxonomic diversity (both at assemblage and global levels), morphological range, and morphological disparity than other geological intervals in the Proterozoic Eon. There seems to be a Tonian increase, relative to the Mesoproterozoic Era, in global taxonomic diversity and morphological range, although this increase is not apparent or significant in terms of assemblage-level taxonomic diversity and morphological variance. Finally, it is likely that the Tonian as a geological period may have greater diversity than the Cryogenian, although there may be second-order dynamics or short-term changes within the Tonian Period [22].

\section{Evolutionary innovations in the Tonian Period}

Important Tonian microfossils that have the potential to shed light on evolutionary innovations include the following: (1) various ornamented acritarchs such as Trachyhystrichosphaera (Figure 3A), Culcitulisphaera, and Cerebrosphaera, which are widely accepted as eukaryotic organisms [33-37]; (2) multicellular eukaryotes such 
A
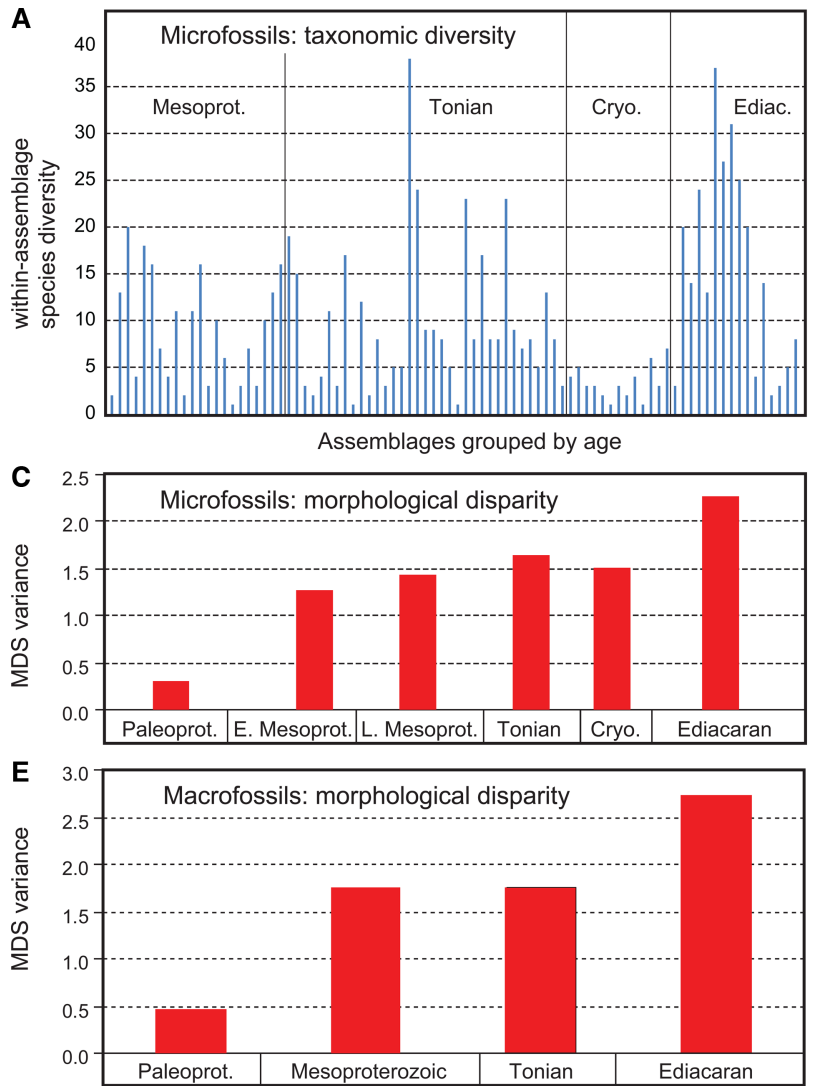
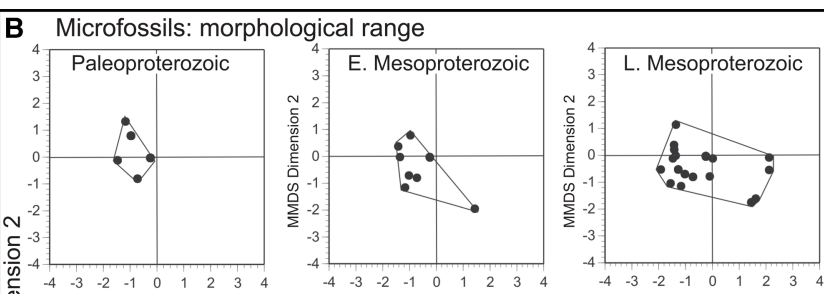

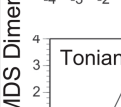
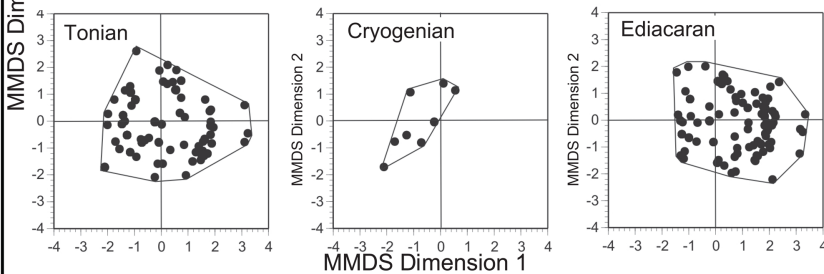

D Macrofossils: morphological range

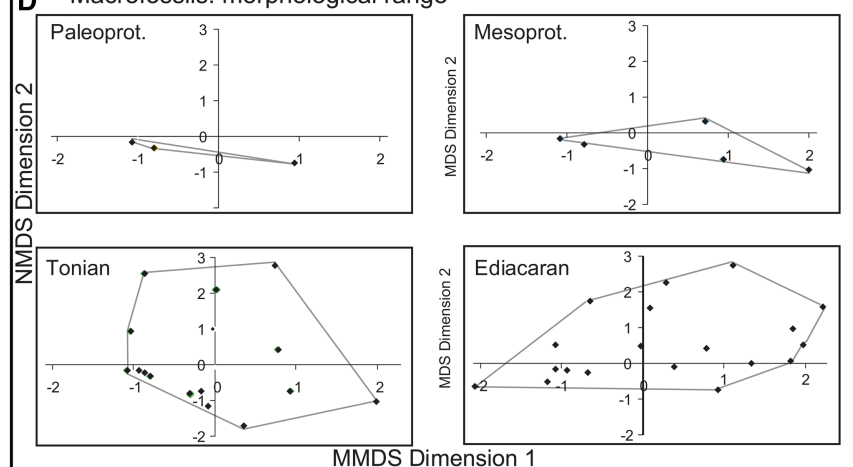

Figure 2. Large-scale diversity trends of Proterozoic eukaryotes.

(A) Within-assemblage species-level taxonomic diversity of Proterozoic eukaryotes (mostly microfossils, although some macrofossils are included). Each bar represents an assemblage. Update from Cohen and Macdonald [20]. Fossils from some stratigraphic units (e.g. the Ediacaran Doushantuo Formation) are broken up into several assemblages because they come from different localities and stratigraphic horizons, highlighting the problem of how to define a fossil assemblage. Also, some microfossils (e.g. apatitic scale microfossils or ASMs from the Tonian Fifteenmile Group) may represent disarticulated sclerites, highlighting the problem of form- and organ-taxa. (B and C) Non-parametric multidimensional scaling (NMDS) analysis of morphological diversity of Proterozoic microfossils [23], showing morphospace range as depicted by convex hulls (B) and morphological disparity as measured by NMDS variances (C). (D and E) NMDS analysis of morphological diversity of Proterozoic macrofossils [31], showing morphospace range as depicted by convex hulls (E) and morphological disparity as measured by NMDS variances (D). Paleoprot. =

Paleoproterozoic; Mesoprot. = Mesoproterozoic; Cryo. = Cryogenian; Ediac. = Ediacaran; E. = Early; L. = Late.

as Proterocladus (Figure 3B), which has been interpreted as a siphonous green alga [38]; Palaeovaucheria (Figure 3C) and Jacutianema, which have been interpreted as putative xanthophytes or members of the stramenophiles $([39,40]$, but see [41]); and Cheilofilum, which has been compared with the extant ascomycete fungus Annellophora ([42], but see [41]); (3) vase-shaped microfossils or VSMs (Figure 3D) that have been interpreted as members of amoebozoans and rhizarians [43-45]; (4) apatitic scale microfossils or ASMs (Figure 3E) that are interpreted as remains of biomineralizing eukaryotes [46].

Tonian macrofossils are relatively few, but they are potentially important in elucidating the evolution of multicellularity and cell differentiation. These include the morphologically simple and stratigraphically longranging genera Tawuia and Chuaria (Figure 3F-G), which may be polyphyletic and include organisms with a multicellular stage in their life cycle [27]. The Tonian macrofossil Longfengshania (Figure 3H) shows evidence of morphological differentiation into a holdfast, a stipe, and a spherical to ellipsoidal thallus, suggesting an affinity with morphologically differentiated multicellular algae based on overall morphological similarities to modern algal analogs [47]. Of significant interest are certain ribbon-shaped macrofossils with transverse annulations, including Sinosabellidites (Figure 3I), Protoarenicola, Pararenicola (Figure 3J), and Parmia [48-50]. These fossils have been variously interpreted as wormlike animals [50,51] or siphonous algae [49,52]. 


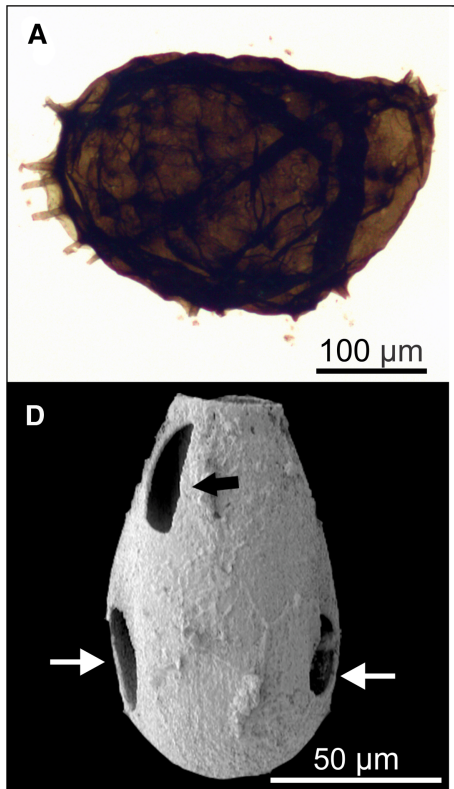

B
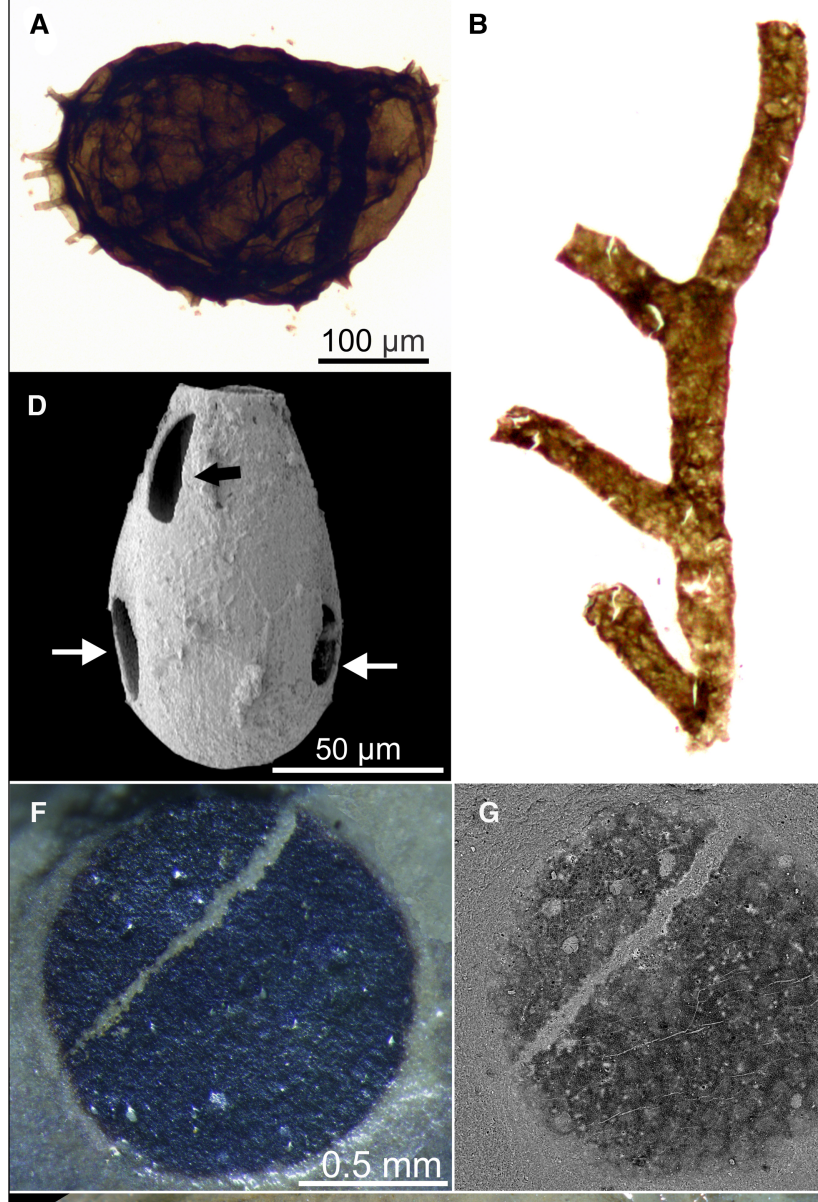

\section{G}
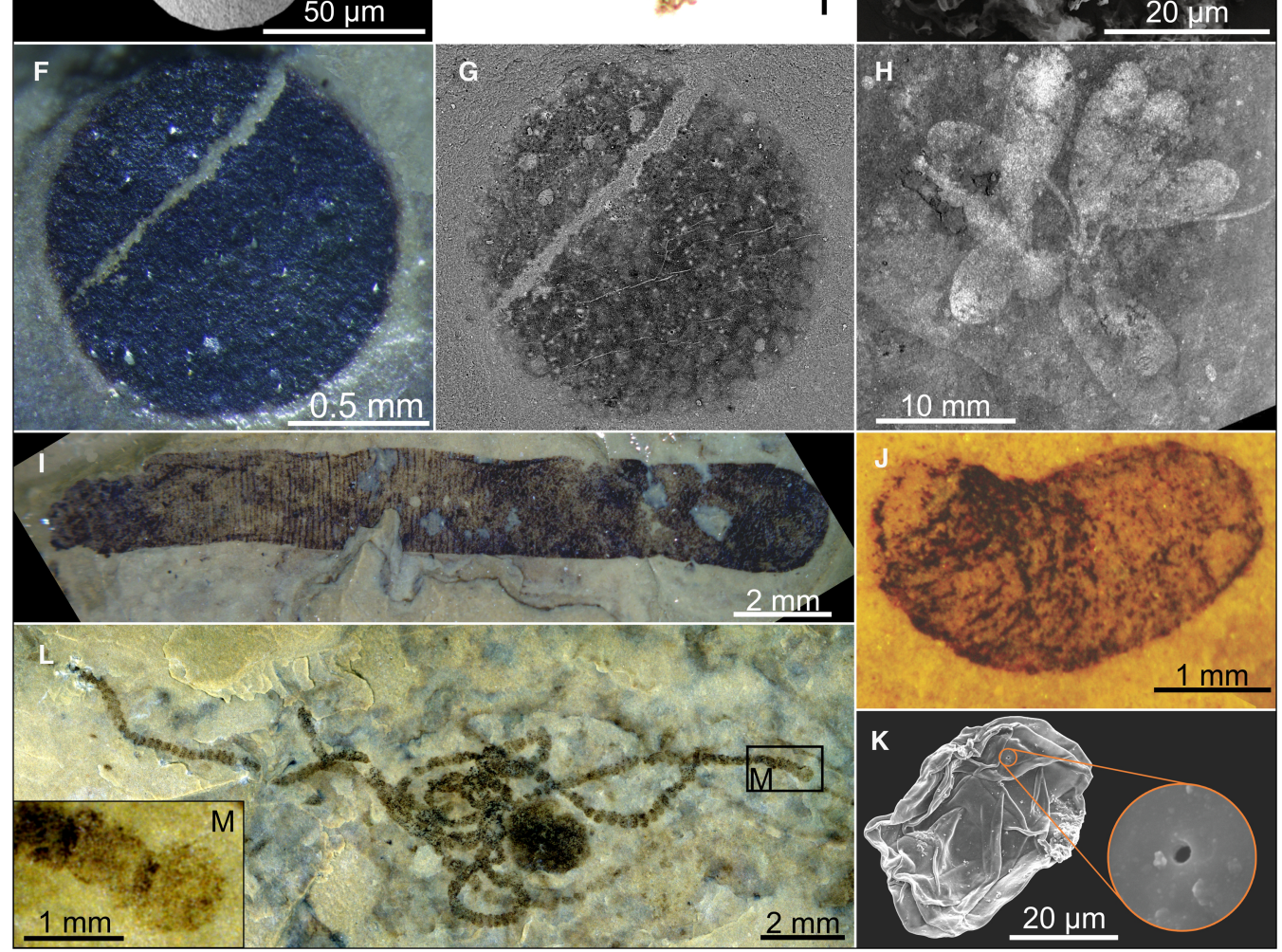

Figure 3. Representative Tonian fossils.

Part 1 of 2

(A) Trachyhystrichosphaera aimika, a spinose acritarch and a likely eukaryote fossil from the Liulaobei Formation in North China.

(B) Proterocladus sp., a possible siphonous green alga from the Nanfen Formation in North China. (C) Palaeovaucheria clavata, a putative xanthophyte alga from the latest Mesoproterozoic-earliest Tonian Lakhanda Group ( 1000 Ma) in southeastern Siberia ([39,40], but see [41]). (D) Cycliocyrillium torquata, an example of vase-shaped microfossils (VSMs) and a possible amoebozoan, from the Kwagunt Formation of the Chuar Group in Arizona [53]. Note circular and semicircular holes (arrows). (E) Quadrireticulum palmaspinosum, an apatitic scale microfossil (ASM), interpreted as a biomineralizing eukaryote, from the Fifteenmile Group in the Yukon Territory, Canada [46]. (F and G) A specimen of Chuaria circularis illustrated under reflected light (F) and backscattered electron SEM to highlight cellular structures (G) [27]. (H) Longfengshania stipitata, a morphologically differentiated multicellular eukaryote from the Little Dal Group in northwestern Canada [47]. (I and J) Sinosabellidites huainanensis and Pararenicola huaiyuanensis, respectively, putative animals or siphonous algae from the Liulaobei Formation in 
North China [51,52]. Note transverse annulations. (K) Leiosphaeridia sp., a smooth-walled acritarch with circular holes (enlargement denoted by the circle) from the Chuar Group in Arizona [53]. (L and $\mathbf{M})$ Anhuithrix magna, a filamentous cyanobacterium with differentiated akinetes (M, enlargement of $\mathbf{L}$ ) from the Liulaobei Formation in North China [55]. (C) courtesy of Andrew H. Knoll. (D and K) courtesy of Susannah Porter. (E) courtesy of Phoebe Cohen. (H) courtesy of the late Precambrian paleontologist Hans Hofmann. (L and $\mathbf{M})$ courtesy of Ke Pang.

Two recent discoveries in Tonian paleontology warrant special highlight here because of their ecosystemwide implications. Porter [53] reported circular and semicircular holes on acritarch vesicles and VSM tests (Figure 3D,K). These holes may have been made by predatory eukaryotes, suggesting the possible presence of eukaryovory (i.e. eukaryotes preying on eukaryotes). It has been proposed that eukaryovory and other ecological interactions may have driven the evolution of novel biochemistry and escalated eukaryote diversification in the Tonian Period [54]. Pang et al. [55] reported a filamentous fossil (Anhuithrix magna) with differentiated cells, and interpreted it as a cyanobacterium with differentiated akinetes (or resting cells) and by implication also heterocysts (or cells specialized for nitrogen fixation) (Figure 3L-M). Because akinetes and heterocysts are only found in the cyanobacterial clade of Nostacales (or subsections IV $+\mathrm{V}$ ), Anhuithrix magna provides a minimum age constraint on the divergence time of the Nostacales. Anhuithrix magna bolsters the Proterozoic fossil record of cyanobacterial akinetes, previously represented by the Paleoproterozoic-Mesoproterozoic genus Archaeoellipsoides [56,57], whose akinete interpretation has been contested [58]. Improving the fossil record of akinetes is important, not only because akinete fossils serve key calibrations for molecular clock estimates of the Nostacales $[18,59,60]$, but also because the development of heterocysts has been hypothesized to be an evolutionary innovation in response to rising $\mathrm{pO}_{2}$ levels ([57], but see discussion below).

To summarize, four extant eukaryote clades (Opisthokonta, Amoebozoa, Plantae, and SAR) may be represented by Tonian fossils, which are regarded as crown-group eukaryotes (Figure 4). These clades thus may have diverged during or before the Tonian Period. The presence of green algae (along with the late Mesoproterozoic red alga Bangiomorpha [19]) and putative xanthophytes in the Tonian Period places minimal age constraints on the origin of primary and secondary plastids, which are key innovations in the evolution of photosynthetic eukaryotes. There is also convincing paleontological evidence for the evolution of eukaryote multicellularity, cell differentiation, biomineralization, eukaryovory, and cyanobacterial heterocysts during or before the Tonian Period [5] (Figure 4).

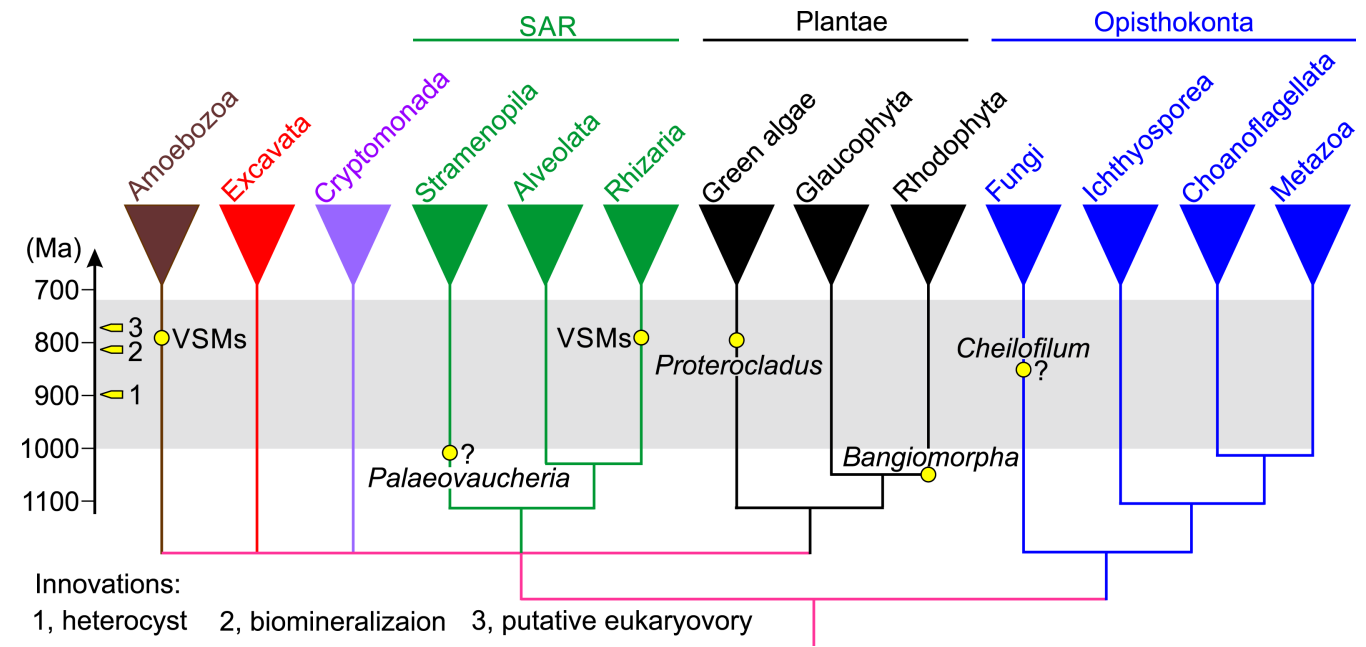

Figure 4. Simplified phylogenetic tree of eukaryotes and Tonian fossils.

Fossils are conservatively placed on the phylogenetic tree (i.e. Bangiomorpha is interpreted as a bangiophyte red alga [41] but is conservatively placed in the total-group Rhodophyta (red algae). The interpretation of Palaeovaucheria as a xanthophyte $[39,40]$ and Cheilofilum as a fungus [72] is not universally accepted [41]. Phylogenetic tree modified from refs. [83,84]. 


\section{Emerging opportunities}

To more accurately characterize the big-picture evolutionary patterns of eukaryotes in the Tonian Period, it is imperative to carry out comprehensive compilation and analysis of both microfossils and macrofossils throughout the entire Proterozoic with the most recent taxonomic treatments and geochronological constraints, to address problems of sampling biases, and to analyze the database with multiple methods and metrics (e.g. both taxonomic and morphological diversity). Some compilations were made more than a decade ago $[21,23,31,61]$, and need to be updated to account for more recent discoveries and new age constraints. Others are more up to date $[20,22,62]$, but they either do not cover the entire Proterozoic Eon or do not contain global diversity data. Among these compilations, only a few recorded morphological characters (as opposed to taxonomic listings) $[23,31]$, yet morphological diversity (independent of taxonomic diversity) is an essential measure of evolutionary success, can provide important insights into large-scale evolutionary patterns, and can alleviate taxonomic problems noted above. With few exceptions $[20,22,23]$, previous analyses have not adequately addressed the problem of sampling biases. Statistical methods have been developed to address sampling biases in the Phanerozoic fossil record, and it is time to carry out comprehensive statistical analysis of the Tonian fossil record in order to adequately address sampling biases.

Phylogenetic interpretation of many Proterozoic acritarchs and carbonaceous macrofossils remains a significant challenge. Only a handful of Tonian fossils have been phylogenetically resolved to major eukaryotic groups. Many are thought to be eukaryotes, but their phylogenetic positions within the total-group eukaryotes are unknown. Some are not resolved even at the broadest phylogenetic level (e.g. bacteria vs. eukaryotes; crown- vs. stem-group eukaryotes, the latter of which were probably common in Proterozoic oceans [63]). It has been shown recently that detailed taxon-specific microstructural, ultrastructural, $\delta^{13} \mathrm{C}_{\text {org }}$, and biomarker analyses of individual fossils can provide important insights into their phylogenetic affinities (e.g. [64-70]. This line of research is currently hampered by the incomplete survey of both Proterozoic fossils and extant analogs, and it presents opportunities to develop novel proxies for phylogenetic interpretation and to test the phylogenetic specificity of existing proxies.

In light of recent molecular clock estimates of a Tonian divergence of crown-group animals $[15,16]$, it is perplexing that thus far no convincing animal fossils have been identified in the Tonian Period. On the other hand, it can be difficult to conclusively identify early animal fossils, because they may have been soft-bodied organisms and unique animal apomorphies have little likelihood of being preserved in the fossil record. Cohen et al. [71] proposed that ultrastructural features of acritarchs can provide phylogenetic insights and they interpreted certain Ediacaran spinose acritarchs as animal resting cysts on the basis of ultrastructures. Few Tonian spinose acritarchs have been investigated for ultrastructures. In this regard, Tonian spinose acritarchs such as Trachyhystrichosphaera (Figure 3A) and 'Tappania' [72] present excellent opportunities for detailed ultrastructural, $\delta^{13} \mathrm{C}_{\text {org }}$, and biomarker analyses in order to constrain their phylogenetic affinities. The same can be said of Tonian carbonaceous compression macrofossils such as Sinosabellidites, Protoarenicola, Pararenicola, and Parmia, which were once interpreted as wormlike animals [50,51] but later as siphonous algae [49,52].

Not only animal and eukaryotic fossils, but also bacterial and particularly cyanobacterial fossils, can provide important insights into biological-environmental co-evolution in the Tonian Period. For example, the recent discovery of akinete-bearing and mat-forming filamentous cyanobacteria from Tonian rocks [55] may have implications for local or even global redox conditions [57]. These akinete-bearing cyanobacteria may have also borne specialized heterocysts for nitrogen fixation, because modern akinetes occur almost exclusively in heterocystous cyanobacteria [55] and modern akinete-bearing cyanobacteria are phylogenetically nested within a clade of heterocystous cyanobacteria [73]. The universal enzyme for nitrogen fixation, nitrogenase, is highly sensitive to oxygen and can be irreversibly inactivated in the presence of free oxygen $[74,75]$. The degree of sensitivity is highly variable, with some diazotrophs showing greater tolerance to oxygen than others [74]. This variability is partly due to the development of various physiological and biochemical strategies to protect nitrogenase [75]. One of these strategies is the development of thick-walled nitrogen-fixing heterocysts in diazotrophic cyanobacteria [76], which have to cope with the conflicting functions of $\mathrm{O}_{2}$-producing photosynthesis and $\mathrm{O}_{2}$-sensitive nitrogen fixation. Among modern diazotrophic cyanobacteria, the optimal ambient $\mathrm{O}_{2}$ concentration for nitrogen fixation can vary from $<12 \mu \mathrm{M}$ in non-heterocystous forms to $300 \mu \mathrm{M}$ in heterocystous forms [74], but nitrogenase activity drops below $10 \%$ of optimal levels when ambient dissolved $\mathrm{O}_{2}$ levels are above $600 \mu \mathrm{M}[77]$. 
As most cyanobacteria carry out oxygenic photosynthesis, it is expected that oxygen concentrations within cyanobacterial cells and mats are higher than the ambient environment. This can be assessed by estimating the excess $\mathrm{O}_{2}$ concentration, or the within-cell or within-mat $\mathrm{O}_{2}$ concentration that is above the ambient $\mathrm{O}_{2}$ level. For planktonic unicellular cyanobacteria, the excess intracellular oxygen due to photosynthesis is related to the photosynthesis rate (which controls $\mathrm{O}_{2}$ production) and cell size (which controls diffusion), but it is negligible $(<0.25 \mu \mathrm{M}$ for cells $<1 \mu \mathrm{m}$ in diameter) due to effective diffusion of oxygen to the ambient environment [78]. However, because of enhanced $\mathrm{O}_{2}$ production and impeded diffusion, excess oxygen concentrations in cyanobacterial colonies and benthic mats can reach $500 \mu \mathrm{M}$ or higher during daytime [78-80]. Indeed, $\mathrm{O}_{2}$ bubbles can form in modern cyanobacterial mats [81], and possible $\mathrm{O}_{2}$ bubbles have been identified in Proterozoic cyanobacterial mats [82]. Thus, the main challenge for diazotrophic cyanobacteria that form colonies, aggregates, and microbial mats is the local production and diffusion of $\mathrm{O}_{2}$, rather than the overall atmospheric $\mathrm{pO}_{2}$ levels or ambient dissolved $\mathrm{O}_{2}$ concentrations per se. In other words, even if atmospheric $\mathrm{pO}_{2}$ levels were low (e.g. in the Paleo- and Mesoproterozoic), there may still be an environmental pressure for the development of physiological and biochemical strategies to protect nitrogenase as long as cyanobacteria form colonies, aggregates, or microbial mats. That said, it remains possible that heterocysts in diazotrophic cyanobacteria may have been an evolutionary innovation in response to the environmental ramifications of rising $\mathrm{pO}_{2}$ levels $[9,13]$. The challenge for paleontologists is to determine whether mat-forming heterocystous cyanobacteria began to diversify in the Tonian Period or much earlier $[55,57,58]$.

To summarize, a key question driving future research of Tonian paleontology is whether the Tonian rise in $\mathrm{pO}_{2}$ levels left a preservable and identifiable paleontological signature. This can be in the form of diversity patterns (e.g. significant Tonian increase in taxonomic and morphological diversity) or evolutionary innovations (e.g. rise of animals, appearance of certain redox-sensitive physiologies). Addressing this question will not only lead to a more comprehensive picture of the Tonian Earth system, but will also inform us about the evolutionary pace in the wake of the 'boring billion' and set a baseline for studying the biological impact of the 'freezing millions' that ensued.

\title{
Summary
}

- The Tonian Period is critical to understanding the transition from the Mesoproterozoic 'boring billion' to the Cryogenian 'freezing millions'.

- There seems to be a Tonian increase in global taxonomic diversity and morphological range relative to the Mesoproterozoic Era.

- Crown-group eukaryotes and major eukaryote groups (including Opisthokonta, Amoebozoa, Plantae, and SAR) may have already diverged by the Tonian Period.

- Important evolutionary innovations (possible eukaryovory, eukaryote biomineralization, and cyanobacterial heterocysts) may have arisen by the Tonian Period.

- Thus far, no convincing animal fossils have been found in the Tonian Period.

\author{
Abbreviations \\ ASM, apatitic scale microfossil; NMDS, non-parametric multidimensional scaling; PAL, present atmospheric \\ level; SAR, eukaryotic clade including Stramenopila, Alveolata, and Rhizaria; SEM, scanning electron \\ microscopy; VSM, vase-shaped microfossil.
}

\section{Funding}

The authors would like to thank National Science Foundation Sedimentary Geology and Paleobiology Program [EAR1528553] and NASA Exobiology and Evolutionary Biology Program [NNX15AL27G] for providing financial 
support; guest editors Tim Lyons, Mary Droser, and Susannah Porter for inviting us to contribute; and two anonymous reviewers for constructive comments.

\section{Competing Interests}

The Authors declare that there are no competing interests associated with the manuscript.

\section{References}

1 Buick, R., Des Marais, D.J. and Knoll, A.H. (1995) Stable isotopic compositions of carbonates from the Mesoproterozoic Bangemall Group, northwestern Australia. Chem. Geol. 123, 153-171 https://doi.org/10.1016/0009-2541(95)00049-R

2 Javaux, E. (2011) Evolution of early eukaryotes in Precambrian oceans. In Origins and Evolution of Life: an Astrobiological Perspective (Gargaud, M., Lopez-Gracia, P. and Martin, H., eds), pp. 414-449, Cambridge University Press

3 Xiao, S. (2013) Written in stone: The fossil record of early eukaryotes. In Evolution From the Galapagos: Social and Ecological Interactions in the Gapalagos Islands 2 (Trueba, G. and Montúfar, C., eds), pp. 107-124, Springer

4 Knoll, A.H. (2014) Paleobiological perspectives on early eukaryotic evolution. Cold Spring Harb. Perspect. Biol. 6, a016121 https://doi.org/10.1101/ cshperspect.a016121

5 Javaux, E.J. and Knoll, A.H. (2017) Micropaleontology of the lower Mesoproterozoic Roper Group, Australia, and implications for early eukaryotic evolution. J. Paleontol. 91, 199-229 https://doi.org/10.1017/jpa.2016.124

6 Javauxa, E.J. and Lepot, K. (2018) The Paleoproterozoic fossil record: implications for the evolution of the biosphere during Earth's middle-age. Earth Sci. Rev. 176, 68-86 https://doi.org/10.1016/j.earscirev.2017.10.001

7 Hoffman, P.F., Abbot, D.S., Ashkenazy, Y., Benn, D.I., Brocks, J.J., Cohen, P.A. et al. (2017) Snowball Earth climate dynamics and Cryogenian geology-geobiology. Sci. Adv. 3, e1600983 https://doi.org/10.1126/sciadv.1600983

8 Lyons, T.W., Reinhard, C.T. and Planavsky, N.J. (2014) The rise of oxygen in Earth's early ocean and atmosphere. Nature 506, 307-315 https://doi.org/10.1038/nature13068

9 Planavsky, N.J., Reinhard, C.T., Wang, X., Thomson, D., McGoldrick, P., Rainbird, R.H. et al. (2014) Low mid-Proterozoic atmospheric oxygen levels and the delayed rise of animals. Science 346, 635-638 https://doi.org/10.1126/science.1258410

10 Zhang, S., Wang, X., Wang, H., Bjerrum, C.J., Hammarlund, E.U., Costa, M.M. et al. (2016) Sufficient oxygen for animal respiration 1,400 million years ago. Proc. Natl Acad. Sci. U.S.A. 113, 1731-1736 https://doi.org/10.1073/pnas.1523449113

11 Gilleaudeau, G.J., Frei, R., Kaufman, A.J., Kah, L.C., Azmy, K., Bartley, J.K. et al. (2016) Oxygenation of the mid-Proterozoic atmosphere: clues from chromium isotopes in carbonates. Geochem. Perspect. Lett. 2, 178-187 https://doi.org/10.7185/geochemlet.1618

12 Guilbaud, R., Poulton, S.W., Butterfield, N.J., Zhu, M. and Shields-Zhou, G.A. (2015) A global transition to ferruginous conditions in the early Neoproterozoic oceans. Nat. Geosci. 8, 466-470 https://doi.org/10.1038/ngeo2434

13 Reinhard, C.T., Planavsky, N.J., Gill, B.C., Ozaki, K., Robbins, L.J., Lyons, T.W. et al. (2017) Evolution of the global phosphorus cycle. Nature $\mathbf{5 4 1}$ 386-389 https://doi.org/10.1038/nature20772

14 Lenton, T.M., Boyle, R.A., Poulton, S.W., Shields-Zhou, G.A. and Butterfield, N.J. (2014) Co-evolution of eukaryotes and ocean oxygenation in the Neoproterozoic era. Nat. Geosci. 7, 257-265 https://doi.org/10.1038/nge02108

15 Erwin, D.H., Laflamme, M., Tweedt, S.M., Sperling, E.A., Pisani, D. and Peterson, K.J. (2011) The Cambrian conundrum: early divergence and later ecological success in the early history of animals. Science 334, 1091-1097 https://doi.org/10.1126/science.1206375

16 dos Reis, M., Thawornwattana, Y., Angelis, K., Telford, M.J., Donoghue, P.C.J. and Yang, Z. (2015) Uncertainty in the timing of origin of animals and the limits of precision in molecular timescales. Curr. Biol. 25, 2939-2950 https://doi.org/10.1016/j.cub.2015.09.066

17 Brocks, J.J., Jarrett, A.J.M., Sirantoine, E., Hallmann, C., Hoshino, Y. and Liyanage, T. (2017) The rise of algae in Cryogenian oceans and the emergence of animals. Nature 548, 578-581 https://doi.org/10.1038/nature23457

18 Sánchez-Baracaldo, P., Raven, J.A., Pisani, D. and Knoll, A.H. (2017) Early photosynthetic eukaryotes inhabited low-salinity habitats. Proc. Natl Acad. Sci. U.S.A. 114, E7737-E7745 https://doi.org/10.1073/pnas.1620089114

19 Gibson, T.M., Shih, P.M., Cumming, V.M., Fischer, W.W., Crockford, P.W., Hodgskiss, M.S.W. et al. (2018) Precise age of Bangiomorpha pubescens dates the origin of eukaryotic photosynthesis. Geology 46, 135-138 https://doi.org/10.1130/G39829.1

20 Cohen, P.A. and Macdonald, F.A. (2015) The Proterozoic record of eukaryotes. Paleobiology 41, 610-632 https://doi.org/10.1017/pab.2015.25

21 Vidal, G. and Moczydłowska-Vidal, M. (1997) Biodiversity, speciation, and extinction trends of Proterozoic and Cambrian phytoplankton. Paleobiology 23, 230-246 https://doi.org/10.1017/S0094837300016808

22 Riedman, L.A. and Sadler, P.M. (2017) Global species richness record and biostratigraphic potential of early to middle Neoproterozoic eukaryote fossils. Precambrian Res. https://doi.org/10.1016/j.precamres.2017.10.008

23 Huntley, J.W., Xiao, S. and Kowalewski, M. (2006) 1.3 billion years of acritarch history: an empirical morphospace approach. Precambrian Res. 144 52-68 https://doi.org/10.1016/..precamres.2005.11.003

24 Han, T.M. and Runnegar, B. (1992) Megascopic eukaryotic algae from the 2.1-billion-year-old Negaunee Iron-Formation, Michigan. Science 257 232-235 https://doi.org/10.1126/science.1631544

25 Sharma, M. and Shukla, Y. (2009) Taxonomy and affinity of Early Mesoproterozoic megascopic helically coiled and related fossils from the Rohtas Formation, the Vindhyan Supergroup, India. Precambrian Res. 173, 105-122 https://doi.org/10.1016/j.precamres.2009.05.002

26 Sharma, M., Mishra, S., Dutta, S., Banerjee, S. and Shukla, Y. (2009) On the affinity of Chuaria-Tawuia complex: a multidisciplinary study. Precambrian Res. 173, 123-136 https://doi.org/10.1016/j.precamres.2009.04.003

27 Tang, Q., Pang, K., Yuan, X. and Xiao, S. (2017) Electron microscopy reveals evidence for simple multicellularity in the Proterozoic fossil Chuaria. Geology 45, 75-78 https://doi.org/10.1130/G38680.1

28 Zhu, S. and Chen, H. (1995) Megascopic multicellular organisms from the 1700-million-year-old Tuanshanzi Formation in the Jixian area, North China Science 270, 620-622 https://doi.org/10.1126/science.270.5236.620 
29 Zhu, S., Sun, S., Huang, X., He, Y., Zhu, G., Sun, L. et al. (2000) Discovery of carbonaceous compressions and their multicellular tissues from the Changzhougou Formation (1800 Ma) in the Yanshan Range, North China. Chin. Sci. Bull. 45, 841-846 https://doi.org/10.1007/BF02887415

30 Zhu, S., Zhu, M., Knoll, A.H., Yin, Z., Zhao, F., Sun, S. et al. (2016) Decimetre-scale multicellular eukaryotes from the 1.56-billion-year-old Gaoyuzhuang Formation in North China. Nat. Commun. 7, 11500 https://doi.org/10.1038/ncomms11500

31 Xiao, S. and Dong, L. (2006) On the morphological and ecological history of Proterozoic macroalgae. In Neoproterozoic Geobiology and Paleobiology (Xiao, S. and Kaufman, A.J., eds), pp. 57-90, Springer

32 Ye, Q., Tong, J., Xiao, S., Zhu, S., An, Z., Tian, L. et al. (2015) The survival of benthic macroscopic phototrophs on a Neoproterozoic snowball Earth. Geology 43, 507-510 https://doi.org/10.1130/G36640.1

33 Tang, Q., Pang, K., Xiao, S., Yuan, X., Ou, Z. and Wan, B. (2013) Organic-walled microfossils from the early Neoproterozoic Liulaobei Formation in the Huainan region of North China and their biostratigraphic significance. Precambrian Res. 236, 157-181 https://doi.org/10.1016/j.precamres.2013.07.019

34 Tang, Q., Pang, K., Yuan, X., Wan, B. and Xiao, S. (2015) Organic-walled microfossils from the Tonian Gouhou Formation, Huaibei region, North China Craton, and their biostratigraphic implications. Precambrian Res. 266, 296-318 https://doi.org/10.1016/.precamres.2015.05.025

35 Riedman, L.A. and Porter, S. (2016) Organic-walled microfossils of the mid-Neoproterozoic Alinya Formation, Officer Basin, Australia. J. Paleontol. 90, 854-887 https://doi.org/10.1017/jpa.2016.49

36 Porter, S.M. and Riedman, L.A. (2016) Systematics of organic-walled microfossils from the ca. 780-740 Ma Chuar Group, Grand Canyon, Arizona. J. Paleontol. 90, 815-853 https://doi.org/10.1017/jpa.2016.57

37 Tang, Q., Hughes, N.C., McKenzie, N.R., Myrow, P.M. and Xiao, S. (2017) Late Mesoproterozoic - early Neoproterozoic organic-walled microfossils from the Madhubani Group of the Ganga Valley, northern India. Palaeontology 60, 869-891 https://doi.org/10.1111/pala.12323

38 Butterfield, N.J., Knoll, A.H. and Swett, K. (1994) Paleobiology of the Neoproterozoic Svanbergfjellet Formation, Spitsbergen. Fossils Strata 34, 1-84 https://doi.org/10.1111/j.1502-3931.1994.tb01558.x

39 Hermann, T.N. (1990) Organic World Billion Year Ago. Nauka

40 Butterfield, N.J. (2004) A vaucheriacean alga from the middle Neoproterozoic of Spitsbergen: implications for the evolution of Proterozoic eukaryotes and the Cambrian explosion. Paleobiology 30, 231-252 https://doi.org/10.1666/0094-8373(2004)030<0231:AVAFTM>2.0.C0;2

41 Butterfield, N.J. (2015) Early evolution of the Eukaryota. Palaeontology 58, 5-17 https://doi.org/10.1111/pala.12139

42 Butterfield, N.J. (2005) Reconstructing a complex early Neoproterozoic eukaryote, Wynniatt Formation, arctic Canada. Lethaia 38, 155-169 https://doi.org/10.1080/00241160510013231

43 Porter, S.M., Meisterfeld, R. and Knoll, A.H. (2003) Vase-shaped microfossils from the Neoproterozoic Chuar Group, Grand Canyon: a classification guided by modern testate amoebae. J. Paleontol. 77, 409-429 https://doi.org/10.1017/S0022336000044140

44 Riedman, L.A., Porter, S.M. and Calver, C.R. (2017) Vase-shaped microfossil biostratigraphy with new data from Tasmania, Svalbard, Greenland, Sweden and the Yukon. Precambrian Res. https://doi.org/10.1016/j.precamres.2017.09.019

45 Cohen, P.A., Irvine, S.W. and Strauss, J.V. (2017) Vase-shaped microfossils from the Tonian Callison Lake Formation of Yukon, Canada: taxonomy, taphonomy and stratigraphic palaeobiology. Palaeontology 60,683-701 https://doi.org/10.1111/pala.12315

46 Cohen, P.A., Strauss, J.V., Rooney, A.D., Sharma, M. and Tosca, N. (2017) Controlled hydroxyapatite biomineralization in an 810 million-year-old unicellular eukaryote. Sci. Adv. 3, e1700095 https://doi.org/10.1126/sciadv.1700095

47 Hofmann, H.J. (1985) The mid-Proterozoic Little Dal macrobiota, Mackenzie Mountains, north-west Canada. Palaeontology 28, 331-354

48 Wang, G., Zhang, S., Li, S., Yan, Y., Dou, S. and Fang, D. (1984) Research on the Upper Precambrian of Northern Jiangsu and Anhui Provinces. Anhui Press of Science and Technology

49 Sharma, M. and Shukla, Y. (2012) Megascopic carbonaceous compression fossils from the Neoproterozoic Bhima Basin, Karnataka, South India. Geol. Soc. Lond. Spec. Publ. 366, 277-293 https://doi.org/10.1144/SP366.5

50 Gnilovskaya, M.B., Veis, A.F., Bekker, A.Y., Olovyanishnikov, V.G. and Raaben, M.E. (2000) Pre-Ediacaran fauna from Timan (Annelidomorphs of the late Riphean). Stratigr. Geol. Correl. 8, 327-352

51 Chen, J. (1988) Precambrian metazoans of the Huai River drainage area (Anhui, E. China): their taphonomic and ecological evidence. Senkenb. Lethaea 69, 189-215

52 Dong, L., Xiao, S., Shen, B., Yuan, X., Yan, X. and Peng, Y. (2008) Restudy of the worm-like carbonaceous compression fossils Protoarenicola, Pararenicola, and Sinosabellidites from early Neoproterozoic successions in North China. Palaeogeogr. Palaeoclimatol. Palaeoecol. 258, 138-161 https://doi.org/10.1016/.ppalaeo.2007.05.019

53 Porter, S.M. (2016) Tiny vampires in ancient seas: evidence for predation via perforation in fossils from the 780-740 million-year-old Chuar Group Grand Canyon, USA. Proc. R. Soc. B: Biol. Sci. 283, 20160221 https://doi.org/10.1098/rspb.2016.0221

54 Brocks, J.J., Jarrett, A.J.M., Sirantoine, E., Kenig, F., Moczydłowska, M., Porter, S. et al. (2016) Early sponges and toxic protists: possible sources of cryostane, an age diagnostic biomarker antedating Sturtian Snowball Earth. Geobiology 14, 129-149 https://doi.org/10.1111/gbi.12165

55 Pang, K., Tang, Q., Chen, L., Wan, B., Niu, C., Yuan, X. et al. (2018) Nitrogen-fixing heterocystous cyanobacteria in the Tonian Period. Curr. Biol. 28 616-622.e1 https://doi.org/10.1016/j.cub.2018.01.008

56 Golubic, S., Sergeev, V.N. and Knoll, A.H. (1995) Mesoproterozoic Archaeoellipsoides: akinetes of heterocystous cyanobacteria. Lethaia 28, 285-298 https://doi.org/10.1111/j.1502-3931.1995.tb01817.x

57 Tomitani, A., Knoll, A.H., Cavanaugh, C.M. and Ohno, T. (2006) The evolutionary diversification of cyanobacteria: molecular-phylogenetic and paleontological perspectives. Proc. Natl Acad. Sci. U.S.A. 103, 5442-5447 https://doi.org/10.1073/pnas.0600999103

58 Butterfield, N.J. (2015) Proterozoic photosynthesis - a critical review. Palaeontology 58, 953-972 https://doi.org/10.1111/pala.12211

59 Schirrmeister, B.E., Gugger, M. and Donoghue, P.C.J. (2015) Cyanobacteria and the Great Oxidation Event: evidence from genes and fossils. Palaeontology 58, 769-785 https://doi.org/10.1111/pala.12178

60 Shih, P.M., Hemp, J., Ward, L.M., Matzke, N.J. and Fischer, W.W. (2017) Crown group Oxyphotobacteria postdate the rise of oxygen. Geobiology 15 19-29 https://doi.org/10.1111/gbi.12200

61 Knoll, A.H., Javaux, E.J., Hewitt, D. and Cohen, P. (2006) Eukaryotic organisms in Proterozoic oceans. Philos. Trans. R. Soc., B: Biol. Sci. 361 1023-1038 https://doi.org/10.1098/rstb.2006.1843 
62 LoDuca, S.T., Bykova, N., Wu, M., Xiao, S. and Zhao, Y. (2017) Seaweed morphology and ecology during the great animal diversification events of the early Paleozoic: a tale of two floras. Geobiology 15, 588-616 https://doi.org/10.1111/gbi.12244

63 Porter, S.M., Agić, H. and Riedman, L.A. (2018) Anoxic ecosystems and early eukaryotes. Emerg. Top. Life Sci. 2, 299-309 https://doi.org/10.1042/ ETLS20170162

64 Javaux, E.J., Knoll, A.H. and Walter, M.R. (2003) Recognizing and interpreting the fossils of early eukaryotes. Origins Life Evol. Biosph. 33, 75-94 https://doi.org/10.1023/A:1023992712071

65 Kaufman, A.J. and Xiao, S. (2003) High $\mathrm{CO}_{2}$ levels in the Proterozoic atmosphere estimated from analyses of individual microfossils. Nature $\mathbf{4 2 5}$ 279-282 https://doi.org/10.1038/nature01902

66 Schiffbauer, J.D. and Xiao, S. (2009) Novel application of focused ion beam electron microscopy (FIB-EM) in preparation and analysis of microfossil ultrastructures: a new view of complexity in early eukaryotic organisms. Palaios 24, 616-626 https://doi.org/10.2110/palo.2009.p09-003r

67 Moczydłowska, M., Schopf, J.W. and Willman, S. (2010) Micro- and nano-scale ultrastructure of cell walls in Cryogenian microfossils: revealing their biological affinity. Lethaia 43, 129-136 https://doi.org/10.1111/j.1502-3931.2009.00175.x

68 Pang, K., Tang, Q., Schiffbauer, J.D., Yao, J., Yuan, X., Wan, B. et al. (2013) The nature and origin of nucleus-like intracellular inclusions in Paleoproterozoic eukaryote microfossils. Geobiology 11, 499-510 https://doi.org/10.1111/gbi.12053

69 Xiao, S., Bykova, N., Kovalick, A. and Gill, B.C. (2017) Stable carbon isotopes of sedimentary kerogens and carbonaceous macrofossils from the Ediacaran Miaohe Member in South China: implications for stratigraphic correlation and sources of sedimentary organic carbon. Precambrian Res. 302 171-179 https://doi.org/10.1016/j.precamres.2017.10.006

70 Bobrovskiy, I., Hope, J.M., Krasnova, A., Ivantsov, A. and Brocks, J.J. (2018) Molecular fossils from organically preserved Ediacara biota reveal cyanobacterial origin for Beltanelliformis. Nat. Ecol. Evol. 2, 437-440 https://doi.org/10.1038/s41559-017-0438-6

71 Cohen, P.A., Knoll, A.H. and Kodner, R.B. (2009) Large spinose microfossils in Ediacaran rocks as resting stages of early animals. Proc. Natl Acad. Sci. U.S.A. 106, 6519-6524 https://doi.org/10.1073/pnas.0902322106

72 Butterfield, N.J. (2005) Probable proterozoic fungi. Paleobiology 31, 165-182 https://doi.org/10.1666/0094-8373(2005)031<0165:PPF>2.0.C0;2

73 Uyeda, J.C., Harmon, L.J. and Blank, C.E.A. (2016) A comprehensive study of cyanobacterial morphological and ecological evolutionary dynamics through deep geologic time. PLOS ONE 11, e0162539 https://doi.org/10.1371/journal.pone.0162539

74 Hill, S. (1988) How is nitrogenase regulated by oxygen? FEMS Microbiol. Rev. 54, 111-129 https://doi.org/10.1111/j.1574-6968.1988.tb02738.x

75 Gallon, J.R. (1992) Reconciling the incompatible: $\mathrm{N}_{2}$ fixation and $\mathrm{O}_{2}$. New Phytol. 122, 571-609 https://doi.org/10.1111/j.1469-8137.1992.tb00087.x

76 Adams, D.G. and Duggan, P.S. (1999) Heterocyst and akinete differentiation in cyanobacteria. New Phytol. 144, 3-33 https://doi.org/10.1046/j. 1469-8137.1999.00505.x

77 Berman-Frank, I., Chen, Y.-B., Gao, Y., Fennel, K., Follows, M.J., Milligan, A.J. et al. (2008) Feedbacks between the nitrogen, carbon and oxygen cycles. In Nitrogen in the Marine Environment (Capone, D.G., Bronk, D.A., Mulholland, M.R. and Carpenter, E.J., eds), pp. 1539-1563, Elsevier Inc

78 Kihara, S., Hartzler, D.A. and Savikhin, S. (2014) Oxygen concentration inside a functioning photosynthetic cell. Biophys. J. 106, 1881-1889 https://doi.org/10.1016/j.bpj.2014.03.031

79 Wieland, A. and Kühl, M. (2006) Regulation of photosynthesis and oxygen consumption in a hypersaline cyanobacterial mat (Camargue, France) by irradiance, temperature and salinity. FEMS Microbiol. Ecol. 55, 195-210 https://doi.org/10.1111/j.1574-6941.2005.00031.x

80 Gingras, M., Hagadorn, J.W., Seilacher, A., Lalonde, S.V., Pecoits, E., Petrash, D. et al. (2011) Possible evolution of mobile animals in association with microbial mats. Nat. Geosci. 4, 372-375 https://doi.org/10.1038/ngeo1142

81 Bosak, T., Bush, J.W.M., Flynn, M.R., Liang, B., Ono, S., Petroff, A.P. et al. (2010) Formation and stability of oxygen-rich bubbles that shape photosynthetic mats. Geobiology 8, 45-55 https://doi.org/10.1111/j.1472-4669.2009.00227.x

82 Knoll, A.H., Wörndle, S. and Kah, L.C. (2013) Covariance of microfossil assemblages and microbialite textures across an upper Mesoproterozoic carbonate platform. Palaios 28, 453-470 https://doi.org/10.2110/palo.2013.p13-005r

83 Katz, L.A. (2012) Origin and diversification of eukaryotes. Annu. Rev. Microbiol. 66, 411-427 https://doi.org/10.1146/annurev-micro-090110-102808

84 He, D., Sierra, R., Pawlowski, J. and Baldauf, S.L. (2016) Reducing long-branch effects in multi-protein data uncovers a close relationship between Alveolata and Rhizaria. Mol. Phylogenet. Evol. 101, 1-7 https://doi.org/10.1016/j.ympev.2016.04.033 